\title{
In Vitro Activity of Balanites aegyptiaca and Tamarindus indica Fruit Extracts on Growth and Aflatoxigenicity of Aspergillus flavus and A. parasiticus
}

\author{
Saifeldin A. F. El-Nagerabi ${ }^{1}$, Abdulkadir E. Elshafie ${ }^{2} \&$ Mohamed R. Elamin $^{3}$ \\ ${ }^{1}$ Department of Biological Sciences and Chemistry, College of Arts and Sciences, University of Nizwa, P.O. \\ Box 33, PC 616, Birkat Al Mouz, Nizwa, Oman \\ ${ }^{2}$ Department of Biology, College of Science, Sultan Qaboos University, P. O. Box 36, PC 123, Al Khoud, \\ Muscat, Oman \\ ${ }^{3}$ Department of Chemistry, Sudan Academy of Science, P. O. Box 268, PC 11111, Khartoum North, Sudan \\ Correspondence: Saifeldin A. F. El-Nagerabi, Department of Biological Sciences and Chemistry, College of Arts \\ and Science, University of Nizwa, Birkat Al Mouz, Nizwa, P. O. Box 33, PC 616, Oman. Tel: 968-9636-5051. \\ E-mail: nagerabi@unizwa.edu.om; nagerabi@hotmail.com
}

Received: June 18, 2013 Accepted: July 5, 2013 Online Published: July 8, 2013

doi:10.5539/jfr.v2n4p68 URL: http://dx.doi.org/10.5539/jfr.v2n4p68

\begin{abstract}
Aflatoxin and especially aflatoxin $\mathrm{B}_{1}\left(\mathrm{AFB}_{1}\right)$ is a carcinogenic secondary metabolite synthesized by certain Aspergillus species. They contaminate natural and processed agricultural and animal products which render them unfit for consumption. The aim of this study was to evaluate the in vitro effects of Balanites aegyptiaca and Tamarindus indica fruit extracts on the growth and aflatoxin secretion of Aspergillus flavus (SQU21) and A. parasiticus (CBS921.7) strains. The two fruit extracts significantly $(P<0.05)$ reduced aflatoxin and did not inhibit mycelial dry weights of the two Aspergillus strains. At different concentrations of balanites (2.5-10\%), the inhibition of total aflatoxin was $49.9-84.8 \%$ for A. flavus (SQU21) and 32.1-84.4\% for A. parasiticus (CBS921.7), whereas the inhibition of aflatoxin Bwas 38.2-81.4\% and 32.8-80.6\% for the two strains. Tamarind fruit extract (2.5-7.5\%) caused $28.8-84.2 \%$ and $40.7-85.5 \%$ reductions in total aflatoxin and $37.1-83.5 \%$ and $33.9-85.9 \%$ in aflatoxin B for the two strains, respectively. None of these extracts inhibited the fungal growth or detoxified synthetic aflatoxin $B_{1}$. We have concluded that these fruits contain various inhibitors to aflatoxin biosynthesis and secretion. Therefore, they can be used in combination as safe green biopreservatives to combat aflatoxin contamination of food.
\end{abstract}

Keywords: aflatoxin, Aspergillus flavus, A. parasiticus, Balanites aegyptiaca, detoxification, Tamarindus indica

\section{Introduction}

Fungal growth on agricultural and animal products occurs under favourable ecological conditions and associated with the production of toxigenic secondary metabolites, many of which can be hazardous to humans and animals health (El-Nagerabi, Elshafie, \& Abdalla, 2001; El-Nagerabi, 2002; El-Nagerabi \& Elshafie, 2000, 2001; Jouany, 2007; Kumar, Basu, \& Rajendran, 2008; Herzallah, 2009; Salem \& Ahmad, 2010). Of these mycotoxins, aflatoxins are the most lethal ones and composed of approximately twenty fungal metabolites secreted by Aspergillus flavus, A. parasiticus, A. mominus and A. pseudotamarii. The major aflatoxins are known as $\mathrm{B}_{1}, \mathrm{~B}_{2}$, $\mathrm{G}_{1}$, and $\mathrm{G}_{2}$ (Sidhu, Chandra, \& Behl, 2009; Banu \& Mathumary, 2010; Liu \& Wu, 2010). The most potent of the four naturally occurring aflatoxins is aflatoxin $\mathrm{B}_{1}$ (AFB1) which is highly toxic, mutagenic and hepatocarcinogenic secondary metabolites (Elshafie, El Mubarak, El Nagerabi, \& Elshafie, 2010; El-Nagerabi, Al-Bahry, Elshafie, \& AlHilali, 2012; El-Nagerabi, Elshafie, AlKhanjari, Al-Bahry, \& Elamin, 2013). Naturally occurring mixes of afaltoxins have been classified as a Group one human carcinogen by the International Agency for Research on Cancer (IARC) and has proved carcinogenicity in many animal species, including some rodents, and fishes (International Program on Chemical Safety) (IPCS) (WHO, 1998; Liu \& Wu, 2010). In addition, aflatoxins have huge impact on the agricultural economy through the loss of crop production and the time costs involved in monitoring and decontaminating efforts. For these reasons, FAO and WHO have imposed regulatory guidelines of $20 \mathrm{ppb}$ of total afaltoxin as maximum tolerance level in food or feed products (Sidhu et 
al., 2009; Banu \& Mathumary, 2010; Elshafie et al., 2010). In some European countries, aflatoxin levels are regulated below $5 \mathrm{ppb}$ (Sidhu et al., 2009; Elshafie et al., 2010). Therefore, it is important to find a practical, cost effective, and non-toxic method to prevent moulds growth and aflatoxin contamination of agricultural products. The use of natural plant extracts and biocontrol agents is an excellent alternative to hazardous chemical preservative. Worldwide, efforts and resources have been devoted to search for new antifungal materials from natural sources to food protection and preservation (Karapýnar, 1989; De et al., 1999; Galvano, Piva, Ritieni, \& Galvano, 2001; Paster, Menasherov, Ravid, \& Juven, 1995; Juglal, Govinden, \& Odhav, 2002; Onyeagba, Ugbogu, Okeke, \& Iroakasi, 2004; Haciscferogullarý et al., Boyraz \& Özcan, 2005; Reddy, \& Muralidharan, 2009).

Balanites aegyptiaca (L.) Del, Balanites "Lalob, Hegleeg" in Arabic which belongs to the Zygophyllaceae is one of the most common wild plant species to dry land of Africa and South Asia (Deshmukh \& Bhuyar, 2009; AlAshaal et al., 2010; Shalaby, El Namaky, Khalil, \& Kandil, 2012). It is known as desert dates and used as edible fruits, fuel wood, charcoal, timber and fodder. The plant is known to be potential of medicinal value and used in herbal medicine. The leaves are edible and effective for sleeping sickness (Sheded, Pulford, \& Hamed, 2006), and diabetes (Morsy, Ahmad, \& Kamel, 2010). The outer rind of fruit used in the treatment the skin diseases, hypoglycemic agent, roots bark as antimalarial, Candida infection, and promising for HIV/AIDS patients (AlAshaal et al., 2010; Cook et al., 1998). On the other hand, Tamarindus indica L. of the family Caesalpinaceae and now drawn up in Fabaceae is commonly known as tamarind tree, is one of the most important multipurpose tree species in India sub-continent (Havinga, Hartl, Putscher, Prehsler, Buchmann, \& Vogl, 2010; Prabhu \& Teli, 2011). Almost all parts of the plant are found to be of some uses. The fruit pulps have been known for a very longtime in food, chemicals and pharmaceuticals (Dagar, Singh, \& Singh, 1995). It is incorporated as seasoning or flavouring agents in food, drink, or beverages, removing off odour of fish, and as sanitizers or remedies for various ailments, management of diabetes mellitus, and immense therapeutic potential in many pathological conditions (Maiti, Jana, Das, \& Ghosh, 2004; Wan Norhana, Nor Azman, Poole, Deeth, \& Dakes, 2009; Dey, Swarup, Saxena, \& Dan, 2011). The fruits are used as laxative or febrifuge and for wound treatment throughout the Sahel and Sudan ecological zones (Havinga et al., 2010).

Many edible plant extracts have been reported to have antifungal activity (De, De Krishna, \& Baneerjee, 1999; Ferhout, Bohatier, Guillot, \& Chalchat, 1999; Masture, Azah, Khozirah, Mawardi, \& Manaf, 1999; Pradeep, Lokesh, \& Ravi, 2003; Reddy et al., 2009; El-Nagerabi et al., 2013). Extracts from fruit rinds of Garciniacowa and G. pendunculata displayed variable levels of inhibition on aflatoxin production and the growth of A. flavus (Joseph, Jayaprakasha, Selvi, Sena, \& Sakariah, 2005). Essential oils extracted from different plants have shown significant antifungal properties (Murali \& Mathela, 1978; Singh, Singh, \& Singh, 1980; Prakash, Singh, Kedia, $\&$ Dubey, 2012). The vegetative growth and aflatoxin production of A. flavus and A. parasiticus were found to be inhibited by many essential oils extracted from various medicinal plants (Montes-Belmont \& Carvajal 1998; Soliman \& Badeaa, 2000; Szczerbanik, Jobling, Morris, \& Holford, 2007; El-Nagerabi et al., 2012). On the other hand, the inhibitory effects of plant extracts on aflatoxin synthesis have been investigated by several authors (Gandomi et al., 2009; Kumar, Shukla, Singh, \& Dubey, 2009; Reddy et al., 2009; Prakash, Shukla, Singh, Mishra, Dubey, \& Kharwar, 2011; El-Nagerabi et al., 2012; Shukla, Singh, Prakash, \& Dubey, 2012). The extracts of different plant parts such as fruits of Azadirachta indica (Bhatngar et al., 1990), leaves and calyx of Hibiscus sabdariffa (Al-Shayeb \& Mabrook, 1984; Da Costa, Geraldo, Arrotéia, \& Kemmelmeier, 2010; El-Nagerabi et al., 2012) and fruit extract of Adansonia digitata (El-Nagerabi et al., 2013) were recommended as good inhibitors to both growth and aflatoxin production of A. flavus and A. parasiticus.

The oil and fruit extracts of balanites were reported to have vast biological activities as anticancer, antihelmenthic (Al Ashaal et al., 2010; Shalaby et al., 2012), useful botanical insecticides (Patil, Salunkea, Patil, Salunkhea, Gavit, \& Maheshwari, 2010), antifungal (Chapagain, Wiesman, \& Lahkim, 2007), larvicidal (Wiesman \& Chapagain, 2006; Chapagain et al., 2008), and molluscicidal activities (Treyvaud, Marston, Dyatmiko, \& Hostettmann, 2000). The highest concentration of saponin rich extract from balanites fruit mesocarp (4\%) showed high (81.1\%) and moderate (34.7\%) growth inhibitions against Pythium ultimum and Alternaria solani, respectively. Weak growth inhibition or weak growth stimulation occurred against Fusarium oxysporum, Colletotrichum coccodes, and Verticillium dahliae (Chapagain et al., 2007). The seed extract of tamarind contains phenolic antioxidant and showed antimicrobial activity (De et al., 1999). The juice extracts significantly reduced Listeria monocytogenes and Salmonella typhimurium populations immediately after washing of the shrimps (Wan Norhana et al., 2009). The phenolic extract of the seeds (1\%) significantly inhibited both Staphyllococcus aureus and Escherichia coli (Prabhu \& Teli, 2011). The ethanol extract of seeds, 
fruits, and dried stem bark was active against several fungi and bacteria (Ross, Megalla, Bishay, \& Awad, 1980; Laurens, Mmboup, Tignokpa, Sylla, \& Masquelier, 1985; Acharya, Gade, \& Rai, 2006).

From the above it is obvious that several attempts have been made to search for effective control methods to combat mould growth and aflatoxin contamination of different plant and animal products. The priority is for testing natural products of no residual effects, eco-friendly, and harmless to both humans and animals and can be used as excellent preservatives to food and feed. Therefore, the objective of the present investigations is to study the in vitro effects of fruit extracts from Balanites aegyptiaca and Tamarindus indica on the growth and aflatoxin secretion of two strains of Aspergillus namely A. flavus (SQU21) and A. parasiticus (CBS921.7). We anticipate that these results will successfully contribute in replacing toxic synthetic chemicals and provide alternative green biocontrol methods to protect food and feed against moulds invasion and aflatoxin secretion.

\section{Materials and Methods}

\subsection{Fungal Strains}

For this study, two aflatoxin producer strains of Aspergillus flavus (SQU21) and A. parasiticus (CBS921.7)[NRR22999] used in our previous studies were selected (El-Nagerabi et al., 2012, 2013). The strain were inoculated on Czapek Dox Agar (CDA) and identified with the help of the taxonomic manual of Raper and Fennell (1965). The growing fungi were used as inocula in the present investigations.

\subsection{Sources and Properties of Fruit Extracts}

The fruit of balanites (Balanites aegyptiaca) and tamarind (Tamarindus indica) were purchased from the local markets of Khartoum, Sudan. From each fruit, $50 \mathrm{~g}$ were added to $100 \mathrm{ml}$ distilled water, mixed with automatic blender at low speed for $2 \mathrm{~min}$ and the mixture was filtered through Whatman filter paper No. 4. The filtrate was kept in refrigerator at $4-5{ }^{\circ} \mathrm{C}$ for further study. The chemical properties of balanites and tamarind were reported by many authors. The majority of the studies focused mainly on the oil extracted from the kernel of balanites fruits. The oil contains $54.53 \%$ unsaturated fatty acid, $11.14 \%$ sterols, $7.1 \%$ proteins, and different concentrations of minor and major elements (Cook, VanderJagt, Pastuszyn, Mounkaila, Glew, \& Glew, 1998; Mohamed, Wolf, \& Spiess, 2002; Sheded et al., 2006; AlAshaal et al., 2010). A mixture of steroidal saponins: Balanitin-6 (28\%) and balanitin-7 (72\%) isolated from balanites kernels (Gnoula, Megalizzi, De Neve, Sauvage, Ribaucour, Guissou, Duez, Dubois, Igrassia, lefranc, Kiss, \& Mijatovic, 2008; Morsy et al., 2010). On the other hand, tamarind fruit pulp contains mainly tartaric acid (8.4-18.0\%), reducing sugars, pectin, tannin, fibers, phenols, and cellulosic materials (Wan Norhana et al., 2009; Prabhu et al., 2011). It contains tannin (7\%), arachidic, behenic, lauric, lignoceric, linoleic, linolenic and stearic acids in addition to geranial and geraniol (AlAshaal, Farghaly, Abd El Aziz, \& Ali, 2006).

\subsection{Inoculation of Aspergillus Strains on Media Containing Balanites and Tamarind Fruit Extracts}

For inoculation of A. flavus (SQU21) and A. parasiticus (CBS921.7) two discs from each fungal inoculum were transferred aseptically to $200 \mathrm{ml}$ sterile yeast malt broth in $250 \mathrm{ml}$ conical flasks containing $0.0 \%, 2.5 \%, 5 \%$, $7.5 \%$ and $10 \%(\mathrm{v} / \mathrm{v})$ from balanites extract and $0.0 \%, 2.5 \%, 3.5 \%, 5 \%$ and $7.5 \%(\mathrm{v} / \mathrm{v})$ from tamarind as described in our recent studies on Hibiscus sabdariffa, Nigella sativa, and A. digitata (El-Nagerabi et al., 2012, 2013). As a negative control, $10 \%$ balanites and 7.5\% tamarind were added to yeast malt broth without any fungal inoculation. Triplicates of the inoculated flasks were incubated at ambient temperature $25-29{ }^{\circ} \mathrm{C}$ for 15 days. Similar sets were prepared and the mycelia of the fungi were filtered and the dry weight was determined using Oven method.

\subsection{Effect of Balanites and Tamarind Fruit Extracts on Pure Aflatoxin $B_{1}$}

Pure aflatoxin powder (Sigma Company) was added to $100 \mathrm{ml}$ sterile distilled water which gave an aflatoxin $\mathrm{B}_{1}$ concentration of $870 \mathrm{ppb}$. To this balanites concentration $(10 \mathrm{ml} / 100 \mathrm{ml})$ and tamarind $(7.5 \mathrm{ml} / 100 \mathrm{ml})$ were added separately to different flasks containing pure aflatoxin $\mathrm{B}_{1}$. The flasks were incubated at $25-29{ }^{\circ} \mathrm{C}$ for a week. The concentration of the aflatoxin $\mathrm{B}_{1}$ was detected.

\subsection{Extraction and Determination of Aflatoxin by Alfa Test-P Affinity}

The extraction method used in similar studies was adopted (El-Nagerabi et al., 2012, 2013). The extraction mixture composed of $200 \mathrm{ml}$ of fungal culture, $5 \mathrm{~g}$ of $\mathrm{NaCl}$ salt and $100 \mathrm{ml}$ extraction solution of methanol: water $(70: 30 \mathrm{~V} / \mathrm{V})$. The filtered mixture was passed through Afla-Test-P Affinity Column at a rate of 1-2 drops per second. To the elute aflatoxin, $1 \mathrm{ml}$ of aflatoxin AflaTest developer was added to cuvette, and the concentration of the aflatoxin was measured using calibrated Vicam fluorometer (Series-4EX) with excitation wavelength of $360 \mathrm{~nm}$ and emission wavelength of $440 \mathrm{~nm}$ (Elshafie \& Al-Shally, 1998). 


\subsection{Statistical Analysis}

In this study, one way ANOVA test (correlation coefficient) was used to determine the variation between the effect of different concentrations of fruit extracts on the growth andaflatoxin secretion by two strains of Aspergillus species compared to the control. The analysis was conducted using statistical package software SPSS of version 11.0.

\section{Results and Discussion}

\subsection{Effects of Fruit Extracts of Balanites and Tamarind on Growth and Aflatoxin Secretion}

The effects of different concentrations of Balanites aegyptiaca (Balanites) and Tamarindus indica (Tamarind) fruit extracts on the total aflatoxin (Figure 1a, 2a), aflatoxin B (Figure 1b, 2b), and mycelia dry weights (Figure 1c, 2c) of A. flavus (SQU21) and A. parasiticus (CBS921.7) were recorded, in order. The total aflatoxin and aflatoxin B production by the two Aspergillus strains were significantly $(P<0.05)$ reduced by the tested concentrations of balanites fruit extract $(2.5,5,7.5$, and $10 \mathrm{~g} / 100 \mathrm{ml})$ and tamarind fruit extract $(2.5,3.5$, 5 , and $7.5 \mathrm{~g} / 100 \mathrm{ml})$ in comparison with the control. On the other hand, the growth and the mycelial dry weights of the two fungal strains were significantly $(P<0.05)$ enhanced by the different concentrations of balanites and tamarind fruit extracts.

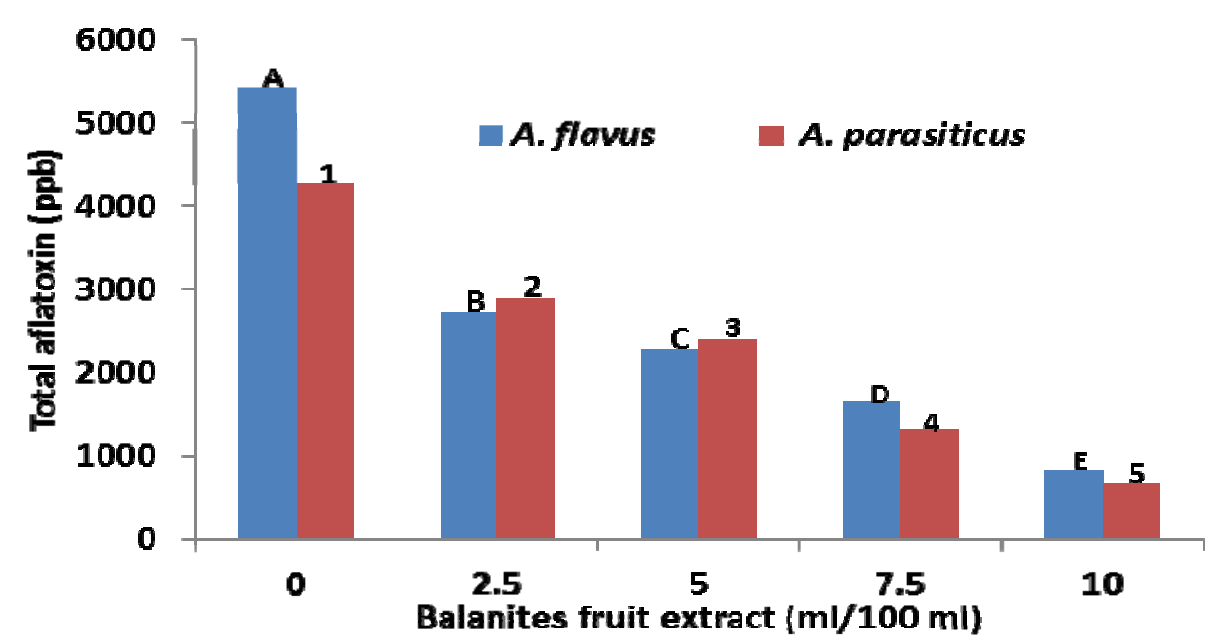

Figure 1a. Total aflatoxin production of A. flavus and A. parasiticus strains at different concentrations of balanites fruit extract (Identical letters and numbers indicate no significant diffrence at $P<0.05$ )

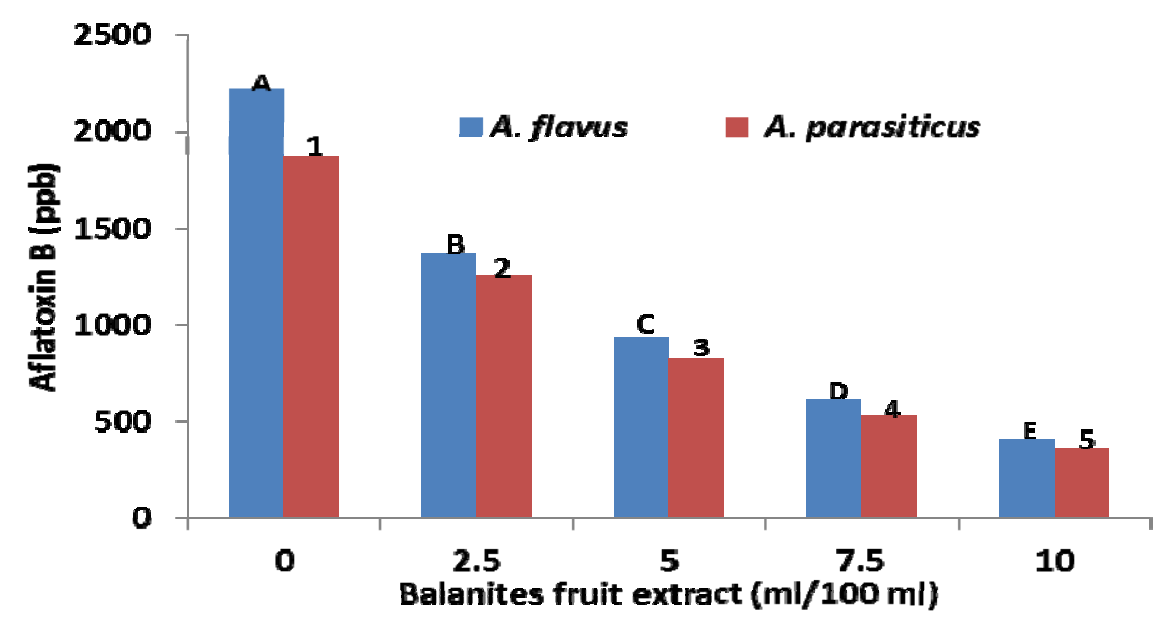

Figure 1b. Aflatoxin B production of A. flavus and A. parasiticus at different concentrations of balanites fruit extract (Identical letters and numbers indicate no significant diffrence at $P<0.05$ ) 


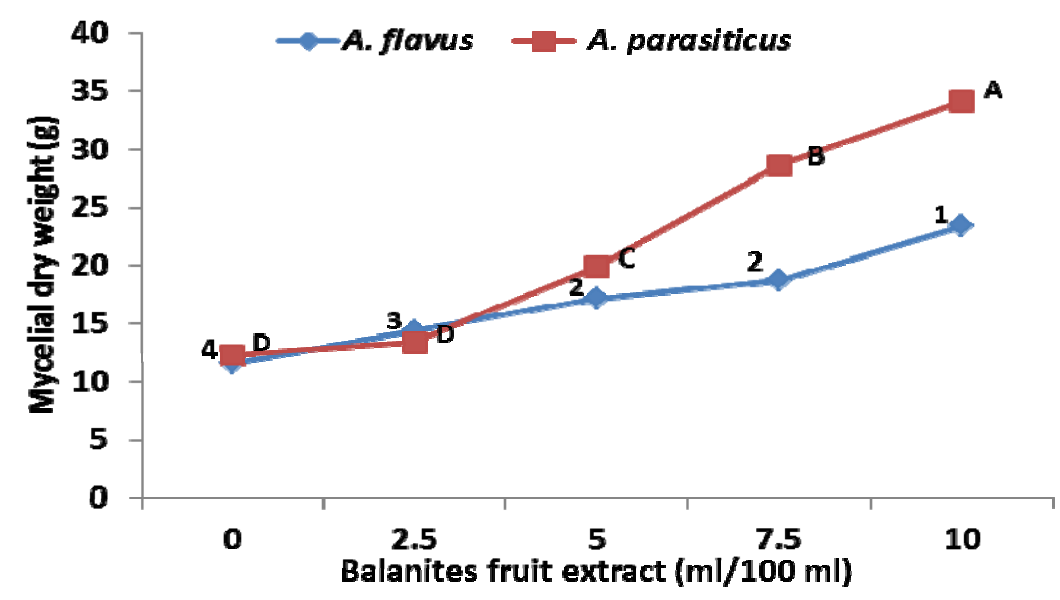

Figure 1c. Mycelial dry weight of A. flavus and A. parasiticus strains at different concentrations of balanites fruit extract (Identical letters and numbers indicate no significant diffrence at $P<0.05$ )

The antifungal activities and inhibitory effects of different plant extracts from herbal and medicinal plants have been under continuous investigation by researchers (Gandomi et al., 2009; Kumar et al., 2009; Oguz, 2011; El-Nagerabi et al., 2012, 2013). These extract include leaves, fruits, and essential oils. However, the antifungal ability and detoxification properties of Balanites aegyptiaca (Balanites) and Tamarindus indica (Tamarind) extracts on the fungal growth and aflatoxins production by Aspergillus species were not investigated and negligible to general information is available on their biological activities. Indian spices including tamarind have potent antimicrobial activities against the test organismsBacillus subtilis (ATCC 6633), Escherichia coli (ATCC 10536) and Saccharomyces cerevisiae (ATCC 9763) (De et al., 1999). To our knowledge, this is the first study focusing on the inhibitory effect of these fruit extracts on aflatoxin production by toxigenic fungi. Extracts from fruit rind of Garcinia cowa and G. penduculata (2000-400 ppb) completely inhibited the growth and aflatoxin $\mathrm{B}_{1}$ production by A. flavus (Joseph et al., 2005). Fruit extract of baobab apparently inhibited the total aflatoxin secretion up to $20.4-68.5 \%$ for $A$. flavus and $11.9-69.1 \%$ for $A$. parasiticus, whereas the inhibition of aflatoxin B1 production ranged between $29.9-79.2 \%$ and $13-68 \%$ for the two strains, respectively (El-Nagerabi et al., 2013). Therefore, it is possible that fruit and other extracts from these two plants could show the same properties on the fungal growth and aflatoxins secretion by A. flavus and A. parasiticus. It is apparently important to test the inhibitory effect of various extracts from Balanites aegyptiaca and Tamarindus indica against the fungal growth and aflatoxin production by aflatoxigenic fungi and compared with the similar studies which used various extracts from herbal and medicinal plants. In the present results, the concentrations of balanites fruit extract $(2.5-10 \%)$ apparently inhibited total aflatoxin production by $49.9-84.8 \%$ for $A$. flavus (SQU21) and 32.1-84.4\% for A. parasiticus (CBS921.7) (Figure 1a), whereas the inhibition of aflatoxin Bproduction(Figure 1b) ranged between $38.2-81.4 \%$ and $32.8-80.6 \%$ for the two strains respectively. On the other hand, the concentrations of tamarind fruit extract (2.5-7.5\%) evidently inhibited total aflatoxin secretion by $28.8-84.2 \%$ for A. flavus (SQU21) and 40.7-85.5\% for A. parasiticus (CBS921.7) (Figure 2a), whereas the inhibition of aflatoxin Bsecretion (Figure $2 \mathrm{~b}$ ) ranged between $37.1-83.5 \%$ and $33.9-85.9 \%$ for the two strains, respectively. Similar findings showed that oil and fruit extracts of balanites have many biological activities as antimutagenic against Fasciola gigantica, Schistosoma mansoni, antiviral activity to Herpes simplex virus, and antimicrobial activities against Gram-positive, Gram-negative bacteria and Candida (Runyoro, Ngassapa, Matee, Joseph, \& Moshi, 2006; Al Ashaal et al., 2010; Shalaby et al., 2012), useful botanical insecticides (Patil et al., 2010), antifungal (Chapagain et al., 2007), larvicidal (Wiesman \& Chapagain, 2006; Chapagain et al., 2008), and molluscicidal activities (Treyvaud et al., 2000). Saponin rich extract from balanites fruit mesocarp (4\%) inhibited the growth of Pythium ultimum by $81.1 \%$ and Alternaria solani by $34.7 \%$. However, low inhibition or stimulation occurs with Fusarium oxysporum, Colletotrichum coccodes, and Verticillium dahliae (Chapagain et al., 2007). Moreover, the phenolic antioxidant extracted from the seed of tamarind revealed antimicrobial activity (De et al., 1999). The juice extracts significantly reduced Listeria monocytogenes and Salmonella typhimurium contaminating the shrimps (Wan Norhana et al., 209). The phenolic extract of tamarind seeds (1\%) significantly inhibited both Staphyllococcus aureus and Escherichia coli (Prabhu \& Teli, 2011). The ethanol extract of seeds, fruits, and dried stem bark was active against several fungi and bacteria, viz, Bacillus cereus, Escherichia coli, 
Pseudomonas aeruginosa, Staphylococcus albus, S. aureus and Sarcina lutea (Ross et al., 1980; Laurens et al., 1985; Acharya et al., 2006). Similar conclusions on the inhibition of the fungal growth and aflatoxin production were reached by many authors using different plant extracts such as fruit rind of $G$. cowa and G. penduculata (200-4000 ppb) (Joseph et al., 2005), fruit (1.5-7\%) and oil extract (0.5-5\%) of Adansonia digitata (El-Nagerabi et al., 2013), neem seed cake and leaf extract (Singh et al., 1980; Bhatngar et al., 1990; Da Costa et al., 2010), leaves extract of Vernonia amygdalina, Sena elata and Cymbopogon citrulus (Suleiman, Emua, \& Taiga, 2008), plant extract of Syzigiumaromaticum, Curcumalonga, Allium sativum and Ocimum sanctum (Reddy et al., 2009), herbal compounds (Gowda, Malathi, \& Suganthi, 2004), and dry leaves and calyx extracts of Hibiscus sabdariffa (Al-Shayeb \& Mabrook 1984; El-Nagerabi et al., 2012). Cinnamon extract concentrations of $0.02-20 \%$ inhibit aflatoxin production by $25-100 \%$, and $2 \%$ of cinnamon led to $97 \%$ inhibition of aflatoxin secretion by aflatoxigenic fungi (Bullerman, Lieu, \& Seier, 1977). About 91.5-97.9\% reduction in aflatoxin $\mathrm{B}_{1}$ production by A. flavus and A. parasiticus was caused by leaf and calyx extracts (5-12.5\%) of $H$. sabdariffa (El-Nagerabi et al., 2012; Al-Shayeb \& Mabrook, 1984). Also essential oils (EOs) extracted from herbal, medicinal and aromatic plants had different fungistatic activities (Soliman \& Badeaa, 2002; Maraqa, Alsharoa, Farah, Albjeirami, Shakya, \& Sallal, 2007; Szczerbanik et al., 2007; Gandomi et al., 2009; Shukla et al., 2012; El-Nagerabi et al., 2012). These include oil of Nigella sativa and Adansonia digitata (Maraqa et al., 2007; El-Nagerabi et al., 2012, 2013); cassia and bay leaves oil (Attanda, Akqan, \& Oluwafemi, 2007), anise, caraway and cinnamon (Farag, Daw, \& Abo-Raya, 1989; Patkar, Usha, Shetty, Poster, \& Lacey, 1993; Hasan 1994; Montes-Belmont \& Carvajal 1998), clove (Bullerman et al., 1977), cinnamon, peppermint, clove and thyme (Montes-Belmont \& Carvajal 1998), Cymbopogon flexuosus (Shukla et al., 2012), Zataria multifora (Gandomi, Misaghi, Basti, Bokaei, Khosravi, Abbasifar, \& Javan, 2009), Ocimum gratissimum (Prakash et al., 2011), and T. eriocalyx and T. $x$-porlock oils (Rasooli \& Abyaneh, 2004). It is, therefore, highly possible that different growth inhibitors may be present in the fruit extracts of balanites and tamarind and affect aflatoxin secretion by these fungi.

In the present study, inoculation of A. flavus (SQU21) and A. parasiticus (CBS921.7) strains on yeast malt broth containing different fruit extracts of balanites $(2.5,5,7.5$, and $10 \mathrm{~g} / 100 \mathrm{ml})$ (Figure 1c) and tamarind $(2.5,3.5,5$, and $7.5 \mathrm{~g} / 100 \mathrm{ml})$ (Figure 2c) significantly $(P<0.05)$ enhanced the fungal growth and mycelial dry weights of the two Aspergillus strains. On the contrary, extract of $H$. sabdariffa apparently retarded the vegetative growth and vigour of different fungi (Guerin \& Revillere 1984). Nonetheless, calyx extract (5-12.5\%) from $H$. sabdariffa did not show any effect on the mycelial growth of Aspergillus species (El-Nagerabi et al., 2012). Some herbal drugs and medicinal plants inhibit the mycelial growth of $A$. flavus and $A$. parasiticus while others improved mycelial growth, but retarded aflatoxin secretion (Bahk \& Marth 1983; Gowda et al., 2004; Joseph et al., 2005; Suleiman et al., 2008; Reddy et al., 2009; Da Costa et al., 2010). The fruit and oil extracts of $A$. digitata significantly reduced the vegetative growth and the mycelial dry weights of $A$. flavus and A. parasiticus (El-Nagerabi et al., 2013). Cinnamon at the concentrations of between $0.02-2.0 \%$ inhibited aflatoxin biosynthesis and the growth of $A$. parasiticus by $16-100 \%$ (Bullerman et al., 1977). The leaf extracts of cassia and bay enhance the mycelial growth of $A$. parasiticus and inhibit the mycelial growth and aflatoxin production by $A$. flavus (Paranagama et al., 2003; Krishnamsrthy \& Shashikala, 2006; Sandosskumar, Karthikeya, Mathiyazhaga, Mohankumar, Chandrasekar, \& Velazhahan, 2007). Therefore, it is evident that fruit extracts of Balanites aegyptiaca and Tamarindus indica displayed no antifungal effect on the growth of either A. flavus or A. parasiticus; however, it apparently inhibited total aflatoxins and aflatoxin B secretion by the two Aspergillus species. Similar findings were reached by using fruit extract of baobab and calyx extract of $H$. sabdariffa, $N$. sativa and A. digitataoils (Maraqa et al., 2007; El-Nagerabi et al., 2012, 2013), oil of cassia and bay leaves (Attanda et al., 2007), and anise and caraway oil (Montes-Belmont \& Carvajal, 1998; Farag et al., 1989; Patkar et al., 1993; Hasan, 1994). It is most likely that different aflatoxin inhibitors may be found in both balanites and tamarind fruit extracts targeting the metabolic pathways of aflatoxin biosynthesis as we concluded in our previous studies (El-Nagerabi et al., 2012).

\subsection{Detoxification of Aflatoxin $B_{1}$ by Fruit Extracts of Balanites and Tamarind}

Detoxifications with biological factors offer green alternatives for aflatoxin elimination and maintaining the quality and safety of food and feed as well as human and animal health (Alberts, Gelderblom, Botha, \& Van Zyl, 2009; Oguz, 2011; Prakash et al., 2011; El-Nagerabi et al., 2012, 2013). The ability of some herbal and medicinal plants as detoxifying agents was reviewed by many researchers (Sandosskumar et al., 2007; El-Nagerabi et al., 2012). This includes garlic (Allium sativum L. x) and onion (Allium cepa L.) roots extracts which cause $58.5 \%$ reduction in aflatoxin $\mathrm{B}_{1}$ (Velazhahan, Vijayanandraj, Vijayasamundeeswari, Parandidharan, Samiyappan et al., 2010). Seed extract of Trachyspermum ammi degraded $90 \%$ of aflatoxin $\mathrm{G}_{1}$ by altering the ring structure of lactone (Velazhahan et al., 2010). The presence of inactivation factors in T. ammi seed extract 
was responsible from $80 \%$ reduction of total aflatoxin content (Hajare, Haijare, \& Sharma, 2006). In the present study, the strains of the two selected Aspergillus species are aflatoxin-producers and secreting different levels of aflatoxins. Nonetheless, the antifungal, inhibitory, and detoxification effects of fruit extracts of Balanites aegyptiaca and Tamarindus indica on the fungal growth and aflatoxin production had not been tested. In the present study, we investigated the effect of $10 \%$ fruit extract of balanites and $7.5 \%$ of tamarind on $780 \mathrm{ppb}$ aflatoxin $\mathrm{B}_{1}$ incubated at $25-29{ }^{\circ} \mathrm{C}$ for 10 days. The results showed that the two extracts have no detoxification effect on pure aflatoxin $B_{1}$. This suggests the non-detoxification properties of these fruit extracts on aflatoxin $B_{1}$. Therefore, it is apparent that fruit extracts of balanites and tamarind had no antifungal and detoxification activities, but inhibit aflatoxin secretion by Aspergillus strains (A. flavus SQU21 and A. parasiticus CBS921.7). This may be attributed to the presence of different afaltoxin inhibitors in the fruit extracts of the two plants as concluded by many authors (Bahk \& Marth, 1983; Chapagain et al., 2007; Banu \& Muthumary, 2010; El-Nagerabi et al., 2012)

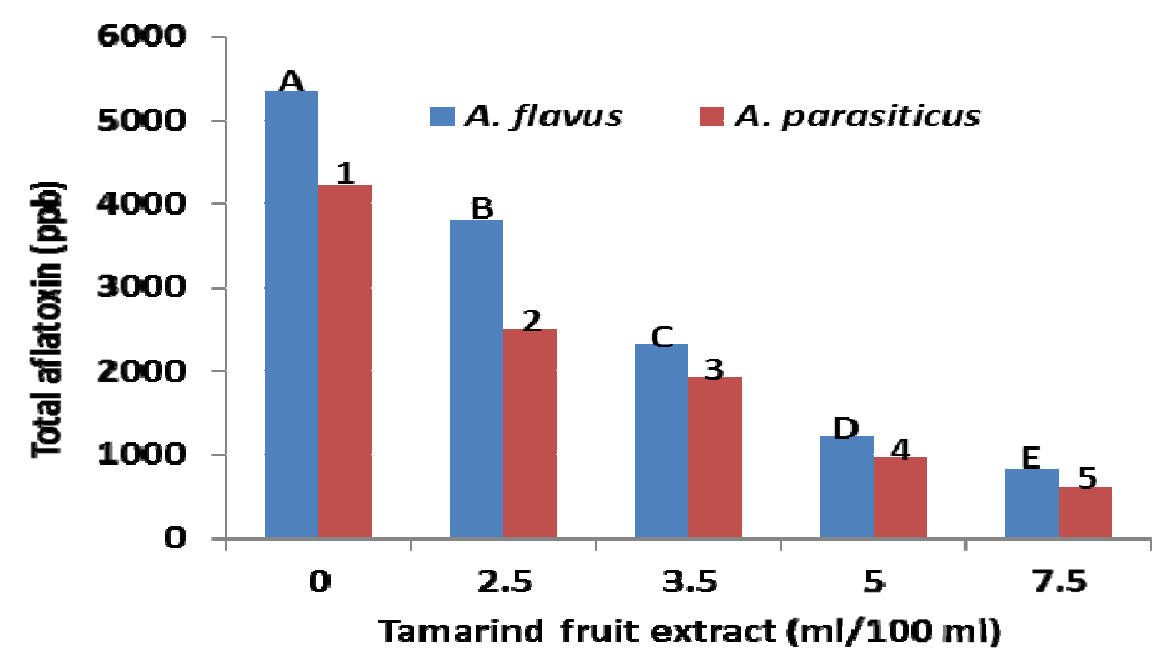

Figure 2a. Total aflatoxin production of A. flavus and A. parasiticus strains at different concentrations of tamarind (Identical letters and numbers indicate no significant diffrence at $P<0.05$ )

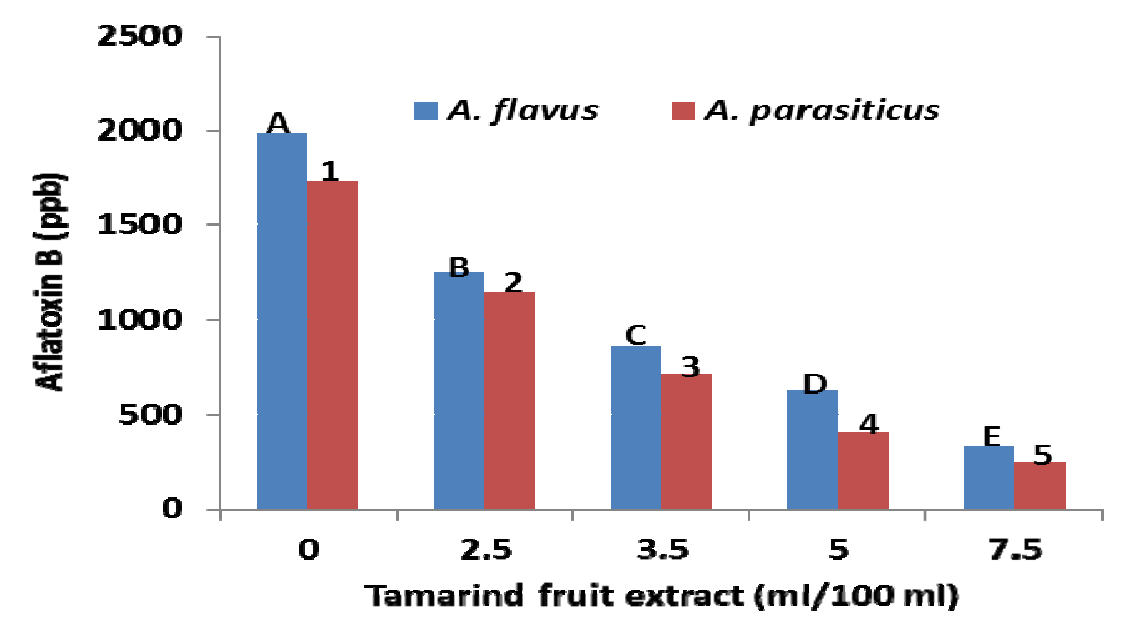

Figure 2b. Aflatoxin B production of A. flavus and A. parasiticus strains at different concentrations of tamarind (Identical letters and numbers indicate no significant diffrence at $P<0.05$ ) 


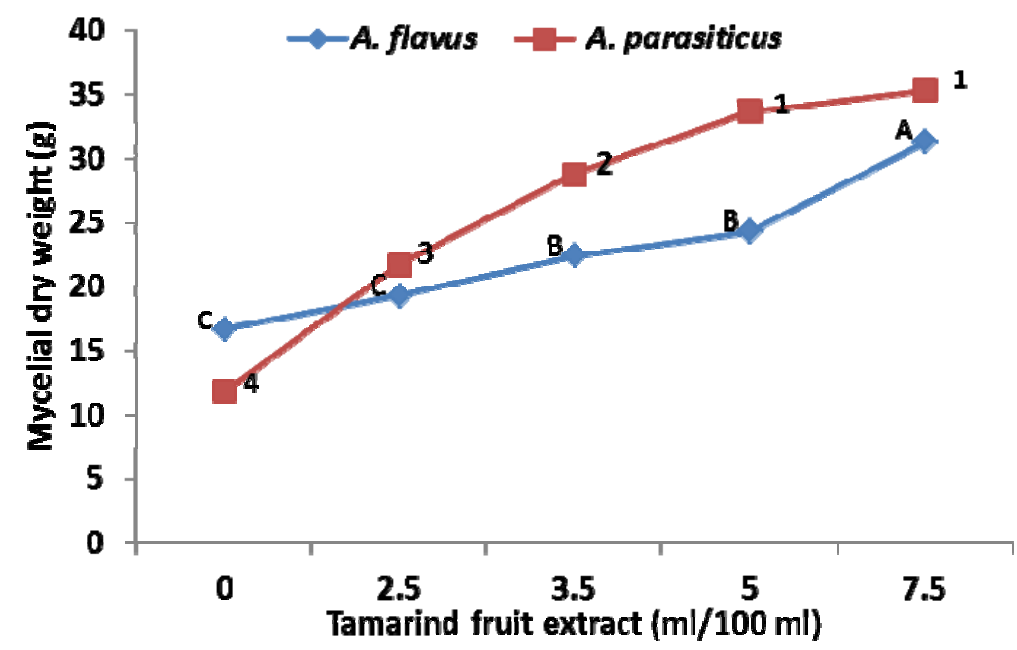

Figure 2c. Mycelial dry weight of $A$. flavus and $A$. parasiticus strains at different concentrations of tamarind (Identical letters and numbers indicate no significant diffrence at $P<0.05$ )

\section{Conclusion}

These investigations reported the in vitro effects of fruit extracts of balanites and tamarind on the growth and inhibition of aflatoxin production by A. flavus (SQU21) and A. parasiticus (CBS921.7) strains. The results showed that both fruit extracts enhanced the mycelial dry weights and evidently inhibited aflatoxins secretion by the two Aspergillus strains and did not detoxify pure aflatoxin $\mathrm{B}_{1}$. This indicates the presence of aflatoxin inhibitors which interfere with the biochemical synthesis of aflatoxin. Therefore, these fruit extracts can be used as botanical additives and biopreservatives to enhance the nutritive value, quality, and protection against aflatoxin infestation. More phytochemical analysis is needed to identify the active chemical constituents and testing their antimicrobial activities against different microorganisms and mycotoxins invasion. This will bring useful information to the field of food biotechnology and related agricultural and pharmaceutical applications.

\section{Acknowledgements}

This research was encouraged by University of Nizwa. We thank the Department of Biological Sciences and Chemistry, College of Arts and Sciences, University of Nizwa and the Department of Biology, College of Science, Sultan Qaboos University for support. We thank the University ofNizwa Writing Center for proof reading the English of this paper.

\section{References}

Acharya, D., Gade, A., \& Rai, M. (2006). Bioactivity of fabaceous plants against food-borne and plant pathogens: potential and limitation. In M. K. Rai \& M. C. Carpinella (Eds.), Naturally occurring bioactive compounds (pp. 125-133), Elsevier B. V. http://dx.doi.org/10.1016/S1572-557X(06)03006-6

Al Ashaal, H. A.,Farghaly, A. A., Abd El Aziz, M. M., \& Ali, M. A. (2010). Phytochemical investigation and medicinal evaluation of fixed oil of Balanites aegyptiaca fruits (Balantiaceae). Journal of Ethnopharmacology, 127(2), 495-501. http://dx.doi.org/10.1016/j.jep.2009.10.007

Alberts, J. F., Gelderblom, W. C. A., Botha, A., \& Van Zyl, W. H. (2009). Degradation of aflatoxin $B_{1}$ by fungal laccaze enzymes. International Journal of Food Microbiology, 135, 47-52.http://dx.doi.org/10.1016/j.ijfoodmicro.2009.07.022

Al-Shayeb, N. M., \& Mabrook, S. S. (1984). Utilization of some edible and medical plants to inhibit aflatoxin formation. Nutrition Report International, 29, 273-282.

Attanda, O. O, Akqan, I., \& Oluwafemi, F. (2007). The potential of some spice oils in the control of $A$. parasiticus CFR 223 and aflatoxin production. Food Control, 18, 601-607. http://dx.doi.org/10.1016/j.foodcont.2006.02.007

Bahk, J., \& Marth, E. H. (1983). Aflatoxin production is inhibited by selected herbal drugs. Mycopathologia, 83, 129-134. http://dx.doi.org/10.1007/BF00437018 
Banu, N., \& Muthumary, J. (2010). Taxol as chemical detoxificant of aflatoxin produced by Aspergillus flavus isolated from sunflower seed. Health, 2, 789-795. http://dx.doi.org/10.4236/health.2010.27119

Boyraz, N., \& Özcan, M. (2005). Antifungal effect of some spice hydrosols. Fitoterapia, 76, 661-665. http://dx.doi.org/10.1016/j.fitote.2005.08.016

Bullerman, L. B., Lieu, F. Y., \& Seier, A. S. (1977). Inhibition of growth and aflatoxin production by cinnamon and clove oils, cinamic aldehyde and eugenol. Journal of Food Science, 42, 1107-1108. http://dx.doi.org/10.1111/j.1365-2621.1977.tb12677.x

Chapagain, B. P., \& Wiesman, Z. (2008). Metabolite profiling of saponins in Balanites aegyptiaca plant tissues using LC (RI)-ESI/MS and MALDI-TOF/MS. Metabolomics, 4, 357-366. http://dx.doi.org/10.1007/s11306-008-0129-z

Chapagain, B. P., Saharan, V., \& Wiesman, Z. (2008). Larvicidal activity of saponins from Balanites aegyptiaca callus against Aedes aegypti mosquito. Bioresource Technology, 99, 1165-1168. http://dx.doi.org/10.1016/j.biortech.2007.02.023

Chapagain, B. P., Wiesman, Z., \& Lahkim, L. T. (2007). In vitro study of the antifungal activity of saponin-rich extracts against prevalent pathogenic fungi. International Crops and Products, 26, 109-115. http://dx.doi.org/10.1016/j.indcrop.2007.02.005

Cook, J. A., VanderJagt, D. J., Pastuszyn, A., Mounkaila, G., Glew, R. S., \& Glew, R. H. (1998). Nutrient content of two indigenous plant foods of Western Sahel: Balanites aegyptiaca and Maerua crassifolia. Journal of Food Composition and Analysis, 11, 221-230. http://dx.doi.org/10.1006/jfca.1998.0582

Da Costa, C. L., Geraldo, M. R. F., Arrotéia, C. C., \& Kemmelmeier, C. (2010). In vitro activity of neem oil [Azadirachta indica A. Juss (Meliaceae)] on Aspergillus flavus growth, sporulation, viability of spores, morphology and aflatoxins $\mathrm{B}_{1}$ and $\mathrm{B}_{2}$ production. Advances in Bioscience and Biotechnology, 1, 292-299. http://dx.doi.org/10.4236/abb.2010.14038

Dagar, J. C., Singh, G., \& Singh, N. T. (1995). Evaluation of crops in agroforestry with teak (Tectoma grandish), maharukh (Ailanthus excelsa) and tamarind (Tamarindus indica) on reclaimed salt effected soil. Journal of Tropical Forest Science, 7(4), 623-634.

De, M., De Krishna, A., \& Baneerjee, A. B. (1999). Antimicrobial screening of Indian spices. Phytotheraphy Research, $13(7)$,

616-618. http://dx.doi.org/10.1002/(SICI)1099-1573(199911)13:7<616::AID-PTR475>3.0.CO;2-V

Deshmukh, S. J., \& Bhuyar, L. B. (2009). Transesterified hingan (Balanites) oil as a fuel for compression ignition engines. Biomass and Bioenergy, 33, 108-112. http://dx.doi.org/10.1016/j.biombioe.2008.04.017

Dey, S., Swarup, D., Saxena, A., \& Dan, A. (2011). In vitro efficacy of tamarind (Tamarindus indica) fruit extract on experimental fluoride exposure in rats. Research in Veterinary Science, 91, 422-425. http://dx.doi.org/10.1016/j.rvsc.2010.09.013

El-Nagerabi, S. A. F. (2002). Determination of seedborne fungi and detection of aflatoxins in Sudanese fenugreek seeds. Phytoparasitica, 30(1), 61-66.http://dx.doi.org/10.1007/BF02983971

El-Nagerabi, S. A. F., \& Elshafie, A. E. (2000). Composition of mycoflora and aflatoxins in lupine seeds from the Sudan. Phytopathologia Mediterranea, 39(2), 257-262.

El-Nagerabi, S. A. F., \& Elshafie, A. E. (2001). Determination of seedborne fungi and aflatoxins in Sudanese guar seeds. Tropical Science, 41(1), 31-35.

El-Nagerabi, S. A. F., \& Elshafie, A. E. (2001). Incidence of seed-borne fungi and aflatoxins in Sudanese lentil seeds. Mycopathologia, 149(3), 151-156. http://dx.doi.org/10.1023/A:1007241125586

El-Nagerabi, S. A. F., Al-Bahry, S. N., Elshafie, A. E., \& AlHilali, S. (2012). Effect of Hibiscus sabdariffa extract and Nigella sativa oil on the growth and aflatoxin $\mathrm{B}_{1}$ production of Aspergillus flavus and Aspergillus parasiticus strains. Food Control, 25, 59-63. http://dx.doi.org/10.1016/j.foodcont.2011.09.033

El-Nagerabi, S. A. F., Elshafie, A. E., \& Abdalla, A. H. (2001). Incidence of fungi and aflatoxins in Sudanese faba bean seeds. University of Khartoum Journal of Agricultural Sciences, 9(1), 82-95.

El-Nagerabi, S. A. F., Elshafie, A. E., \& Abdalla, A. H. (2001). Composition of mycoflora and aflatoxins in pea seeds from the Sudan. Kuwait Journal of Science and Engineering, 27(1), 109-121. 
El-Nagerabi, S. A. F., Elshafie, A. E., AlKhanjari, S. S., Al-Bahry, S. N., Elamin, M. R. (2013). The potential of baobab (Adansonia digitata L.) extracts as biocontrol agent on the growth and aflatoxin production by Aspergillus flavus and A. parasiticus. Journal of Food Research, 2(3), 93-103. http://dx.doi.org/10.5539/jfr.v2n3p93

Elshafie, A. E., \& Al-Shally, N. S. (1998). Mycoflora and mycotoxigenic moulds of pistachio nuts for human consumption in the Sultanate of Oman. Science Technology, 3, 1-6.

Elshafie, S. Z. B., El Mubarak, A., El Nagerabi, S. A. F., \& Elshafie, A. E. (2010). Aflatoxin B contamination of traditionally processed peanut butter for human consumption in Sudan. Mycopathologia, 171(6), 435-439. http://dx.doi.org/10.1007/s11046-010-9378-2

Farag, R., Daw, Z., \& Abo-Raya, S. (1989). Influence of some spice essential oil on A. parasiticus growth and production of aflatoxins in a synthetic medium. Journal of Food Science, 54(1), 74-76. http://dx.doi.org/10.1111/j.1365-2621.1989.tb08571.x

Ferhout, H., Bohatier, J., Guillot, J., \& Chalchat, J. C. (1999). Antifungal activity of selected essential oils, cinnamaldehyde and carvacol against Malassezia furfur and Candida albicans. Journal of Essential Oil Research, 11,119-129. http://dx.doi.org/10.1080/10412905.1999.9701086

Galvano, F., Piva, A., Ritieni, A., \& Galvano, G. (2001). Dietary strategies to counteract the effects of mycotoxins. Review of Journal of Food Protection, 64, 110-131.

Gandomi, H., Misaghi, A., Basti, A. A., Bokaei, S., Khosravi, A., Abbasifar, A., \& Javan, A. J. (2009). Effect of Zataria multifora Bioss. Essential oil on growth and aflatoxin formation by Aspergillus flavus in culture media and cheese. Food and Chemical Toxicology, 47, 2397-2400. http://dx.doi.org/10.1016/j.fct.2009.05.024

Gnoula, C., Megalizzi, V., De Neve, N., Sauvage, S., Ribaucour, F., Guissou, P., ... Mijatovic, T. (2008). Balanitin-6 and -7: diosgenyl saponins isolated from Balanites aegyptiaca Del. display significant anti-tumor activity in vitro and in vivo. International Journal Oncology, 32(10), 5-15.

Gowda, N. K. S., Malathi, V., \& Suganthi, R. U. (2004). Effect of some chemical and herbal compounds on growth of Aspergillus parasiticus and aflatoxin production. Animal Feed Science and Technology, 116, 281-291. http://dx.doi.org/10.1016/j.anifeedsci.2004.02.008

Hajare, S. S., Haijare, S. H., \& Sharma, A. (2006). Aflatoxin inactivation suing aqueous extract of Ajowan (Trachyspermum ammi) seeds. Journal of Food Science, 70, 29-34. http://dx.doi.org/10.1111/j.1365-2621.2005.tb09016.x

Hasan, H. A. H. (1994). Inhibition of mycoflora and zearalenone on rice by selected essential oils. Pakistan Journal of Scientific and Industrial Research, 37(11), 471-473.

Havinga, R. M., Hartl, A. H., Putscher, J., Prehsler, S., Buchmann, C., \& Vogl, C. R. (2010). Tamarindus indica L. (Fabaceae): Patterns of use in traditional African medicine. Journal of Ethnopharmacology, 127, 573-588. http://dx.doi.org/10.1016/j.jep.2009.11.028

Herzallah, S. M. (2009). Determination of aflatoxins in eggs, milk, meat and meat products using HPLC fluorescent and UV detectors. Food Chemistry, 114, 1141-1146. http://dx.doi.org/10.1016/j.foodchem.2008.10.077

International Programme on Chemical Safety and WHO (1998). International programme on chemical safety. Safety evaluation of certain food additives and contaminants. WHO Food Additives Series 40. Retrieved from http://www.inchem.org/documents/jecfa/jecmono/v040je01.htm.

Joseph, G. S., Jayaprakasha, G. K., Selvi, A. T., Sena, B. S., \& Sakariah, K. K. (2005). Antiaflatoxigenic and antioxidant activities of Garcinia extract. International Journal of Food Microbiology, 101, 153-160. http://dx.doi.org/10.1016/j.ijfoodmicro.2004.11.001

Jouany, J. P. (2007). Methods for preventing, decontaminating and minimizing the toxicity of mycotoxin in feed. Animal Feed Science and Technology, 137, 342-362. http://dx.doi.org/10.1016/j.anifeedsci.2007.06.009

Juglal, S., Govinden, R., \& Odhav, B. (2002). Spice oils for the control of co-occurring mycotoxin producing fungi. Journal of Food Protection, 65, 683-687.

Karapy'nar, M. (1989). Inhibition effects of some spice agents on aflatoxigenic mould growth. In International food symposium, 4-6 April, Bursa,Turkey (pp. 129-137). Proceeding book. 
Krishnamsrthy, Y. L., \& Shashikala, J. (2006). Inhibition of aflatoxin B production of Aspergillus flavus, isolated from soybean seeds by certain natural plant products. Letters in Applied Microbiology, 43, 469-474. http://dx.doi.org/10.1111/j.1472-765X.2006.02011.x

Kumar, A., Shukla, R., Singh, P., \& Dubey, N. K. (2009). Biodeterioration of some herbal raw materials by storage fungi and aflatoxin and assessment of Cymbopogon flexuous essential oil and its components as antifungal. International Biodeterioration and Biodegradation, 63, 712-726. http://dx.doi.org/10.1016/j.ibiod.2009.03.011

Kumar, V., Basu, M. S., \& Rajendran, T. P. (2008). Mycotoxin research and mycoflora in some commercially $\begin{array}{lllll}\text { important agricultural } & \text { commodities. } & \text { Crop Protection, } & \text { 27, }\end{array}$ http://dx.doi.org/10.1016/j.cropro.2007.12.011

Laurens, A., Mmboup, S., Tignokpa, M., Sylla, O., \& Masquelier, J. (1985). Antimicrobial activities of some medicinal species of Dakar markets. Phasmazie, 40, 482-485.

Liu, Y., \& Wu, F. (2010). Global burden of aflatoxin-induced hepatocellular carcinoma: A risk assessment. Environmental Health Perspectives, 118, 818-824. http://dx.doi.org/10.1289/ehp.0901388

Maiti, R., Jana, D., Das, U. K., \& Ghosh, D. (2004). Antidiabitic effect of aqueous extract of seed of Tamarindus indica in streptozontocin-induced diabetic rats. Journal of Ethnopharmacology, 92, 85-91. http://dx.doi.org/10.1016/j.jep.2004.02.002

Maraqa, A., Alsharoa, N. F., Farah, H., Albjeirami, W. M., Shakya, A. K., \& Sallal, A. J. (2007). Effect of Nigella sativa extract and oil on aflatoxin production by Aspergillus flavus. Turkish Journal of Biology, 31, 155-159.

Masture, M., Azah, M., Khozirah, S., Mawardi, R., \& Manaf, A. A. (1999). Anticandidal and antidermatophytic activity of Cinnmomum species essential oils. Cytobios, 98, 17-23.

Mohamed, A. M., Wolf, W., \& Spiess, W. E. L. (2002). Physical, morphological and chemical characteristics, oil recovery and fatty acid composition of Balanites aegyptiaca Del. kernels. Plant Foods for Human Nutrition, 57,179-189. http://dx.doi.org/10.1023/A:1015237612018

Montes-Belmont, R., \& Carvajal, M. (1998). Control of Aspergillus flavus in maize with plant essential oils and their components. Journal of Food Protection, 61(5), 616-619.

Morsy, A. M. A., Ahmad, I. A., Kamel, A. M. (2010). Some biomedical applications of Balanites aegyptiaca grown naturally in radioactive area. Southeastern Desert, Egypt. Journal of Hazardous Materials, 178, 725-728. http://dx.doi.org/10.1016/j.jhazmat.2010.02.002

Murali, N. D., \& Mathela, C. S. (1978). Antifungal study of some indigenous essential oils. Indian Perfume, 4, 291-292.

Oguz, H. (2011). A review from experimental trials on detoxification of aflatoxin in poultry feed. Eurasian Journal of Veterinary Sciences, 27, 1-12. http://www.ejvs.selcuk.edu.tr/cms/dokuman/47/1-40.pdf

Onyeagba, R. A., Ugbogu, O. C., Okeke, C. U., \& Iroakasi, O. (2004). Studies on the antimicrobial effects of garlic (Allium sativum Linn) ginger (Zingiber officinale Roscoe) and lime (Citrus aurantifolia Linn). African Journal of Biotechnology, 3, 552-554.

Paster, N., Menasherov, M., Ravid, U., \& Juven, B. (1995). Antifungal activity of oregano and thyme essential oils applied as fumigants against fungi attacking stored grain. Journal of Food Protection, 58, 81-85.

Patil, S. V., Salunkea, B. K., Patil, C. D., Salunkhea, R. B., Gavit, P., \& Maheshwari, V. (2010). Potential of extracts of the tropical plant Balanites aegyptiaca (L) Del. (Balanitaceae) to control the mealy bug, Maconellicoccus hirsutus (Homoptera: Pseudococcidae). Crop Protection, 29, 1293-1296. http://dx.doi.org/10.1016/j.cropro.2010.05.016

Patkar, K., Usha, C., Shetty, H., Poster, N., \& Lacey, J. (1993). Effect of spice essential oils on growth and aflatoxin B1 production by A. flavus. Letter in Applied Microbiology, 17(2), 49-51. http://dx.doi.org/10.1111/j.1472-765X.1993.tb00367.x

Prabhu, K. H., \& Teli, M. D. (2011). Eco-dyeing using Tamarindus indica L. seed coat tannin as a natural mordant for textile with antibacterial activity. Journal of Saudi Chemical Society, In press. http://dx.doi.org/10.1016/j.jscs.2011.10.014 
Pradeep, A. G., Lokesh, S., \& Ravi, V. R. (2003). Efficacy of some essential oils on seed mycoflora and seedling quality of some crop species saved by farmers. Advances in Plant Sciences, 16, 53-58.

Prakash, B., Shukla, R., Singh, P., Mishra, P. K., Dubey, N. K., \& Kharwar, R. N. (2011). Efficacy of chemically characterized Ocimum gratissimum L. essential oil as an antioxidant and a safe plant based antimicrobial against fungal and aflatoxin $\mathrm{B}_{1}$ contamination of spices. Food research International, 44, 385-390. http://dx.doi.org/10.1016/j.foodres.2010.10.002

Prakash, B., Singh, P., Kedia, A., \& Dubey, N. K. (2012). Assessment of some essential oil as food preservatives based on antifungal, antiaflatoxin, antioxidant activities and in vitro efficacy in food system. Food Research International, 49, 201-208. http://dx.doi.org/10.1016/j.foodres.2012.08.020

Raper, K. B., \& Fennell, D. I. (1965). The genusAspergillus (pp. 686). Baltimore: The Williams and Wilkins Company.

Rasooli, I., \& Abyaneh, M. R. (2004). Inhibitory effects of Thyme oils on growth and aflatoxin production by Aspergillus parasiticus. Food Control, 15, 479-483. http://dx.doi.org/10.1016/j.foodcont.2003.07.002

Reddy, K. R. N., Reddy, C. S., \& Muralidharan, K. (2009). Potential of botanicals and biocontrol agents on growth and aflatoxin production by Aspergillus flavus infecting rice grains. Food Control, 20, 173-178. http://dx.doi.org/10.1016/j.foodcont.2008.03.009

Ross, S. A., Megalla, S. E., Bishay, D. W., \& Awad, A. H. (1980). Studies for determining antibiotic substances in some Egyptian plants. Fitoterapia, 51,303-308.

Runyoro, D. K., Ngassapa, O. D., Matee, M. I. N., Joseph, C. C., \& Moshi, M. J. (2006). Medicinal plants used by Tanzanian traditional healers in the management of Candida infections. Journal of Ethnopharmacology, 106, 158-165. http://dx.doi.org/10.1016/j.jep.2005.12.010

Salim, N. M., \& Ahmad, R. (2010). Mycotoxins in food from Jordan: preliminary survey. Food Control, 21, 1099-1103. http://dx.doi.org/10.1016/j.foodcont.2010.01.002

Sandosskumar, R., Karthikeya, M., Mathiyazhaga S., Mohankumar, M., Chandrasekar, G., \& Velazhahan, R. (2007). Inhibition of Aspergillus flavus growth and detoxification of aflatoxin B by medicinal plant zimnu (Allium sativum L. x Allium cepa L.). World Journal of Microbiology and Biotechnology, 23, 1007-1014. http://dx.doi.org/10.1007/s11274-006-9327-x

Shalaby, H. A., El Namaky, A. H., Khalil, F. A., \& Kandil, O. M. (2012). Efficacy of methanolic extract of Balanites aegyptiaca fruits on Toxocara vitulorum.Veterinary Parasitology, 183, 386-392. http://dx.doi.org/10.1016/j.vetpar.2011.07.045

Sheded, M. G., Pulford, I. D., \& Hamed, A. I. (2006). Presence of major and trace elements in seven medicinal plants growing in the South-Eastern Desert, Egypt. Journal of Arid Environment, 66, 210-217. http://dx.doi.org/10.1016/j.jaridenv.2005.10.022

Shukla, R., Singh, P., Prakash, B., \& Dubey, N. K. (2012). Antifungal, aflatoxin inhibition and antioxidant activity of Callistemon lanceolatus (Sm.) sweet essential oil and its major component 1,8-cineole against fungal isolates from chickpea. Food Control, 25, 27-33. http://dx.doi.org/10.1016/j.foodcont.2011.10.010

Sidhu, O. P., Chandra, H., \& Behl, H. M. (2009). Occurrence of aflatoxins in mahua (Madhuca indica Gmel.) seeds: Synergistic effect of plant extracts on inhibition of Aspergillus flavus growth and aflatoxin production. Food and Chemical Toxicology, 47, 774-777. http://dx.doi.org/10.1016/j.fct.2009.01.001

Singh, U. P., Singh, H. B., \& Singh, R. B. (1980). The fungicidal effect of neem (Azadiracta Indica) extracts on some soil borne pathogens of gram (Cicer arietinum). Mycologia, 72, 1077-1093. http://dx.doi.org/10.2307/3759561

Soliman, K. M., \& Badeaa, R. I. (2002). Effect of oil extracted from some medicinal plants on different mycotoxigenic fungi. Food and Chemical Toxicology, 40, 1669-1675. http://dx.doi.org/10.1016/S0278-6915(02)00120-5

Suleiman, M. N., Emua, S. A., \& Taiga, A. (2008). Effect of aqueous extracts on a spot fungus (Fusarium sp.) isolated from cowpea. American-Eurasian Journal of Sustainable Agriculture, 2, 261-263.

Szczerbanik, M., Jobling, J., Morris, S., \& Holford, P. (2007). Essential oil vapours control some common postharvest pathogens. Australian Journal of Experimental Agriculture, 47, 103-109. http://dx.doi.org/10.1071/EA05236 
Treyvaud, V., Marston, A., Dyatmiko, W., \& Hostettmann, K. (2000). Molluscicidal saponins from Phytolacca icosandra. Phytochemistry, 55, 603-609. http://dx.doi.org/10.1016/S0031-9422(00)00233-8

Velazhahan, R., Vijayanandraj, S., Vijayasamundeeswari, A., Parandidharan, V., Samiyappan, R., Iwamoto, T., ... Muthukrishnan, S. (2010). Detoxification of aflatoxin by seed extracts of the medicinal plants, Trachyspermum ammi (L.) Sprangue ex Turrill-structural analysis and biological toxicity of degradation product of aflatoxin $\mathrm{G}_{2}$. Food Control, 21, 719-725. http://dx.doi.org/10.1016/j.foodcont.2009.10.014

Wan Norhana, M. N., Nor Azman, M. A., Poole, S. E., Deeth, H. C., \& Dakes, G. A. (2009). Effect of Bilimbi (Averrhoa bilimbi L.) and tamarind (Tamarindus indica L.) juice on listeria monocytogenes Scott A and Salmonella typhimurium ATCC 14028 and sensory properties of raw shrimps. International Journal of Food Microbiology, 135(1), 88-94. http://dx.doi.org/10.1016/j.ijfoodmicro.2009.09.011

Wiesman, Z., \& Chapagain, B. P. (2006). Larvicidal activity of saponin containing extracts and fractions of fruit mesocarp of Balanites aegyptiaca. Fitoterapia, 77, 420-424. http://dx.doi.org/10.1016/j.fitote.2006.09.001

\section{Copyrights}

Copyright for this article is retained by the author(s), with first publication rights granted to the journal.

This is an open-access article distributed under the terms and conditions of the Creative Commons Attribution license (http://creativecommons.org/licenses/by/3.0/). 